\title{
Method for Measuring Capillary Permeability and its Use in Patients with Skin Disease
}

\author{
JANET MARKS,* B.M., B.CH., M.R.C.P. ; SAM SHUSTER, † M.B., PH.D., M.R.C.P.
}

Brit. med. F., 1966, 2, 88-90

Alterations in capillary permeability in disease have not proved easy to measure. Methods used previously include measurement of haematocrit and plasma protein before and after a period of venous congestion (Landis, Jonas, Angevine, and Erb, 1932), measurement of disappearance from plasma of Evans blue (T 1824) (Weinbren, 1963) and ${ }^{131}$ I human serum albumin (Ismail, Khalifa, and Madwar, 1965), and simultaneous determination of plasma volume by $\mathrm{T} 1824$ and high-molecularweight dextran (Verel, 1958). This is a report of a new method and of the findings obtained with it in patients with skin disease.

\section{Patients and Methods}

Principle of Method.-In a patient whose capillaries are permeable to albumin, plasma volume calculated from dilution of ${ }^{131}$ I human serum albumin will be higher than that calculated indirectly from measurements of red-cell volume and haematocrit. The difference between these two volumes can be used as an index of capillary permeability.

Subjects Studied.-All patients had been admitted to hospital on account of their skin disease. One group of 11 had extensive eczema or psoriasis ; the other group of nine had skin disease in remission or localized to a small area. In addition to these two groups, three patients-one with cyclical oedema, one with dermatomyositis, and one with erythema nodosum-were investigated.

Red-cell volume and plasma volume were measured, one immediately after the other, by the method of Hart and Metz (1962), with slight modification.

Blocking Thyroid Gland.-The patient was given $1 \mathrm{~g}$. of potassium iodide the night before the test, followed by $100 \mathrm{mg}$. on three successive nights.

Haematocrit.-Venous blood taken at the time of the test was centrifuged for five minutes in a Hawksley microhaematocrit centrifuge. The haematocrit used in the calculation was the mean of the readings in three tubes. No correction was made for trapped plasma (Dacie and Lewis, 1963).

In-vitro Labelling of Erythrocytes. $-15 \mathrm{ml}$. of the patient's blood was mixed with $5 \mathrm{ml}$. of acid-citrate dextrose anticoagulant and centrifuged for 20 minutes at 500 r.p.m. The packed cells were left for 30 minutes at room temperature with $50 \mu \mathrm{g}$. of ${ }^{51} \mathrm{Cr}$ sodium chromate of specific activity $50-150 \mathrm{c} / \mathrm{g}$. $\mathrm{Cr}$ (Radiochemical Centre, Amersham). The cells were washed twice with $0.9 \% \mathrm{NaCl}$ and then resuspended in the $\mathrm{NaCl}$, giving a final volume of about $15 \mathrm{ml}$.

Preparation of Standard.-Exactly $1 \mathrm{ml}$. of the cell-suspension was haemolysed with a pinch of saponin, the volume being made up to $100 \mathrm{ml}$. with water.

Measurement of ${ }^{51} \mathrm{Cr}$ Plasma Volume.-The rest of the cell suspension was injected into an arm vein, the volume being estimated from the weight of the syringe before and after the

\footnotetext{
* Senior Registrar and Research Assistant, Department of Dermatology, University of Newcastle upon Tyne, Royal Victoria Infirmary, Newcastle upon Tyne.

† Professor of Dermatology, University of Newcastle upon Tyne, Royal Victoria Infirmary, Newcastle upon Tyne.
}

injection. A sample of blood was taken from another vein 15 minutes after the injection, and $5 \mathrm{ml}$. of whole blood was haemolysed with saponin. The activity of this sample was compared with that of $5 \mathrm{ml}$. of standard solution by means of a well-type scintillation counter containing a 2 -in. $(5-\mathrm{cm}$.) thallium-activated sodium iodide crystal. The time taken for 10,000 counts was recorded for each specimen (standard error $1 \%) .{ }^{51} \mathrm{Cr}$ red-cell volume was calculated from the isotope dilution at 15 minutes and the venous haematocrit. ${ }^{51} \mathrm{Cr}$ blood volume (B.V.) and ${ }^{51} \mathrm{Cr}$ plasma volume (P.V.) were then calculated thus:

$$
{ }^{51} \mathrm{Cr} \mathrm{B.V} .=\frac{\text { R.C.V. }}{\mathrm{H} \times 0.91}
$$

where $0.91=$ whole-body/venous haematocrit ratio (Chaplin, Mollison, and Vetter, 1953)

$$
{ }^{51} \mathrm{Cr} \text { P.V.=B.V. - R.C.V. }
$$

Preparation of ${ }^{191}$ I Human Serum Albumin for Injection.${ }^{131}$ I human serum albumin (Radiochemical Centre, Amersham, free $\mathrm{I}<5 \%$ ) was diluted with $0.9 \% \mathrm{NaCl}$, so that $15 \mathrm{ml}$. contained $2 \mu \mathrm{c}$ of ${ }^{131} \mathrm{I}$. In order to prevent the absorption of labelled albumin on to glass, inert human serum albumin was added to give a final concentration of albumin of $1 \%$.

Preparation of Standard.-To $1 \mathrm{ml}$. of the above solution a few crystals of potassium iodide and $5 \mathrm{ml}$. of $10 \%$ sodium hydroxide were added. This procedure hydrolysed the protein and diluted the radioactive iodide with inactive carrier, thus preventing the uptake of ${ }^{131} \mathrm{I}$ by the glass. The volume was then made up to $100 \mathrm{ml}$. with water.

Measurement of ${ }^{15 I} I$ Human Serum Albumin Plasma Volume.-The rest of the solution was injected intravenously through the needle used to withdraw the ${ }^{51} \mathrm{Cr}$ sample, the volume being measured as before by weighing the syringe. In most of the patients an extra specimen of blood, taken immediately before the albumin injection, showed that no ${ }^{51} \mathrm{Cr}$ was present in the plasma at that time. Ten minutes after the injection blood was taken from a third vein and the activity of $5 \mathrm{ml}$. of plasma compared with that of $5 \mathrm{ml}$. of standard solution. ${ }^{131} \mathrm{I}$ human serum albumin plasma volume was then calculated from the dilution of the isotope at 10 minutes.

Oedema-free Body-zveight.-This was used as the criterion in predicting plasma volume in a given individual. Some patients were oedema-free at the time of the estimation. In other cases the body-weight which had been recorded in the hospital notes before the onset of the oedema was used; if this was not available the body-weight was measured after recovery. In three patients whose weight was not recorded before the illness and who were still being treated with systemic corticosteroids the normal weight as remembered by the patient himself was used in the calculations.

\section{Results}

The results in patients with localized skin disease are shown in the Table. Plasma volume measured by ${ }^{51} \mathrm{Cr}$ and ${ }^{131} \mathrm{I}$ human serum albumin shows considerable variation between individuals, which can partly be attributed to differences in body- 
weight. Despite the differences between individuals there was good agreement between plasma volume measured by the two methods. In calculating the ${ }^{51} \mathrm{Cr}$ plasma volume a whole-body/ venous haematocrit ratio of 0.91 was used. This ratio was calculated for the control patients, and ranged from 0.89 to 0.98 , with a mean of 0.91 , which agrees well with that of Chaplin et al. (1953).

The results in patients with generalized skin disease are also shown in the Table. The ${ }^{131} \mathrm{I}$ plasma volume was greater than the ${ }^{51} \mathrm{Cr}$ plasma volume in all patients, and this increase was often considerable. The ${ }^{131} \mathrm{I}$ plasma volume was significantly greater than that of controls $(t=3.69, P<0.01)$, and the difference between ${ }^{131}$ I plasma volume and plasma volume predicted from oedema-free body-weight (42.3 ml./kg., Cohen, Freeman, and McFarlane, 1961) differed significantly from $0(t=3.48$, $\mathrm{P}<0.01)$. As compared with patients with localized skin disease, the range of ${ }^{51} \mathrm{Cr}$ plasma volume was greater, though the means did not differ significantly.

Plasma Volume and Capillary Permeability

\begin{tabular}{|c|c|c|c|c|c|c|}
\hline \multirow[b]{2}{*}{$\begin{array}{l}\text { Case } \\
\text { No. }\end{array}$} & \multirow{2}{*}{$\begin{array}{l}\text { Age } \\
\text { and } \\
\text { Sex }\end{array}$} & \multirow[b]{2}{*}{ Diagnosis } & \multicolumn{3}{|c|}{ Plasma Volume (ml.) } & \multirow{2}{*}{$\begin{array}{c}\% \\
\begin{array}{c}\% \\
\text { Difference } \\
(\mathrm{b}-\mathrm{c})\end{array} \\
\mathrm{c}\end{array}$} \\
\hline & & & $\begin{array}{c}\text { Predicted } \\
\text { (42.3 ml./kg. } \\
\text { Body-weight) } \\
\text { (a) }\end{array}$ & $\begin{array}{c}{ }^{131} \text { I H.S.A. } \\
\text { (b) }\end{array}$ & $\begin{array}{l}{ }^{51} \mathrm{Cr} \\
\text { (c) }\end{array}$ & \\
\hline
\end{tabular}

\begin{tabular}{|c|c|c|c|c|c|c|}
\hline \multicolumn{7}{|c|}{ Patients with Localized Skin Disease } \\
\hline \multirow{7}{*}{$\begin{array}{l}1 \\
2 \\
3 \\
4 \\
4 \\
5 \\
6 \\
6 \\
7 \\
8 \\
9\end{array}$} & \multirow{3}{*}{$\begin{array}{ll}58 & M \\
52 & \mathrm{~F} \\
58 & \mathrm{M} \\
75 & \mathrm{M} \\
34 & \mathrm{M}\end{array}$} & \multirow{7}{*}{ 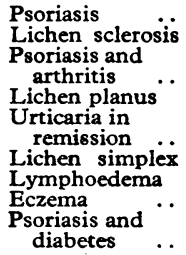 } & $\begin{array}{l}2,670 \\
2,690\end{array}$ & $\begin{array}{l}2,970 \\
2,400\end{array}$ & $\begin{array}{l}2,830 \\
2,290\end{array}$ & $\begin{array}{l}4.9 \\
4.8\end{array}$ \\
\hline & & & 2,430 & 2,450 & 2,370 & 3.4 \\
\hline & & & 2,950 & 3,100 & 3,000 & 3.3 \\
\hline & \multirow{4}{*}{$\begin{array}{cc}68 & M \\
35 & F \\
45 & M \\
60 & F\end{array}$} & & 2,950 & 2,950 & 2,880 & $2 \cdot 4$ \\
\hline & & & $\begin{array}{l}2,760 \\
2,820\end{array}$ & $\begin{array}{l}3,800 \\
2,850\end{array}$ & $\begin{array}{l}3,760 \\
2,830\end{array}$ & $\begin{array}{l}1.1 \\
0.7\end{array}$ \\
\hline & & & 1,940 & 2,370 & 2,450 & -3.3 \\
\hline & & & 3,150 & 2,750 & 2,900 & $-5 \cdot 2$ \\
\hline & & & & & Mean & $1 \cdot 3$ \\
\hline
\end{tabular}

\begin{tabular}{|c|c|c|c|c|c|c|}
\hline \multicolumn{7}{|c|}{ Patients with Generalized Skin Disease } \\
\hline 10 & $45 \mathrm{~F}$ & $\begin{array}{l}\text { Exfoliative } \\
\text { dermatitis }\end{array}$ & 2,570 & & & \\
\hline 11 & $57 \mathrm{~F}$ & Erythrodermic & ט, & 4,500 & 2,100 & 105.0 \\
\hline 12 & $72 \mathrm{M}$ & $\begin{array}{c}\text { psoriasis } \\
\text { Exfoliative }\end{array} \quad \cdots$ & 2,940 & 5,100 & 3,760 & $35 \cdot 5$ \\
\hline 13 & $44 \mathrm{M}$ & $\underset{\text { Erythrodermic }}{\text { dermatitis }}$. & 2,800 & 3,550 & 3,150 & $12 \cdot 6$ \\
\hline 14 & $60 F$ & $\begin{array}{c}\text { psoriasis } \\
\text { Exfoliative }\end{array}$ & 3,330 & 4,500 & 4,050 & $11 \cdot 1$ \\
\hline & & $\begin{array}{l}\text { dermatitis } \\
\text { Exfoliative }\end{array}$ & 2,220 & 2,950 & 2,700 & $9 \cdot 3$ \\
\hline 15 & $\stackrel{0}{M}\{$ & $\begin{array}{l}\text { dermatitis ... } \\
\text { After recovery } \\
\text { Exfoliative }\end{array}$ & $\begin{array}{l}2,170 \\
2,170\end{array}$ & $\begin{array}{l}3,520 \\
2,960\end{array}$ & $\begin{array}{l}3,230 \\
2,910\end{array}$ & $\begin{array}{l}9 \cdot 0 \\
1 \cdot 7^{*}\end{array}$ \\
\hline & & dermatitis .. & 2,900 & 3,450 & 3,170 & $8 \cdot 8$ \\
\hline & & eczema & 2,820 & 3,500 & 3,250 & $7 \cdot 7$ \\
\hline 18 & $65 \mathrm{M}$ & $\begin{array}{l}\text { Widespread } \\
\text { psoriasis }\end{array}$ & & & & \\
\hline 19 & $55 \mathrm{M}$ & "̈, “ & 3,850 & 3,480 & $\begin{array}{l}2,470 \\
3,320\end{array}$ & $4 \cdot 8$ \\
\hline & & psoriasis & 2,600 & 2,430 & 2,060 & $1 \cdot 8$ \\
\hline & & & & & Mean & $19 \cdot 2$ \\
\hline
\end{tabular}

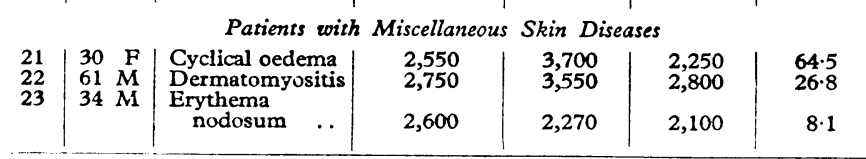

* Not used in calculating mean.

The patients with cyclical oedema, dermatomyositis, and erythema nodosum all had a ${ }^{13}{ }^{1}$ p plasma volume that was larger than the ${ }^{51} \mathrm{Cr}$ plasma volume (see Table).

\section{Discussion}

The principle of this method of measuring capillary permeability to human serum albumin depends upon the reference of protein leakage to red-cell mass. The assumption is made that erythrocytes remain in the vascular compartment without sequestration, so that mixing with the ${ }^{51} \mathrm{Cr}$-tagged cells is complete. A second assumption that the whole-body/venous haematocrit ratio is relatively constant at about 0.9 appears to hold in a variety of situations (Chaplin et al., 1953). This ratio is essentially an index of the difference in plasma volume measured directly and calculated indirectly from red-cell volume and haematocrit, and it is assumed to be due to pooling of plasma in the peripheral vessels. It seems possible, however, that part of this difference is due to normal capillary filtration of plasma-protein-bound marker, since the human serum albumin used contained less than $5 \%$ free iodine. We have nevertheless made the conventional correction from venous to whole-body haematocrit.

With this method capillary permeability to human serum albumin was found to be increased in all but one patient with generalized skin disease, and this increase was often considerable. Capillary permeability was also found to be increased in the patients with cyclical oedema, dermatomyositis, and erythema nodosum. We have no evidence whether the increased capillary permeability is confined to the vessels of the skin ; but only the patient with erythema nodosum had albuminuria, and there was no evidence of protein loss through the gut, though this may occur in patients with extensive skin disease (Shuster and Wilkinson, 1963 ; Marks and Shuster, 1965).

In the patients with generalized skin disease the mean ${ }^{51} \mathrm{Cr}$ plasma volume was not significantly different from that of the controls with localized skin disease, though the range was greater. The increase in plasma volume which had previously been reported in patients with extensive skin disease (Shuster and Wilkinson, 1963 ; Fox, Shuster, Williams, Marks, Goldsmith, and Condon, 1965) was presumably an overestimate due to this increased permeability to human serum albumin.

Despite the greatly increased capillary filtration of plasma these patients had achieved equilibrium in that absorption was presumably keeping pace with filtration. Failure to maintain this hyperdynamic equilibrium may occur, and with serious consequences. Shortly after admission patient 15 collapsed with hypotension, oliguria, and clinical hypovolaemia in the presence of considerable and increasing oedema of the skin. We have no record of his plasma volume at this time, but his serum-albumin concentration had fallen to $1.5 \mathrm{~g} . / 100 \mathrm{ml}$. Treatment with systemic and topical corticosteroids to decrease capillary permeability, together with intravenous infusion of 1.5 1. of triple-strength plasma, produced a rapid improvement. Milder forms of this syndrome are not uncommon in patients with exfoliative dermatitis and erythrodermia, and will be described elsewhere. The high mortality of these diseases (Wilson, 1954 ; Abrahams, McCarthy, and Sanders, 1963) is partly due to thermoregulatory and haemodynamic abnormalities (Fox et al., 1965). To this we must now add the consequences of a sudden increase in capillary permeability.

\section{Summary}

Capillary permeability was measured by comparing the dilution of ${ }^{131}$ I human serum albumin with that of ${ }^{51} \mathrm{Cr}$-tagged erythrocytes after intravenous injection.

With the use of this method in control subjects with localized skin disease an average of $1.3 \%$ of the plasma volume was filtered in 10 minutes. Very considerable increases in filtration were found in patients with exfoliative dermatitis and erythrodermic psoriasis and in a further three patients suffering from cyclical oedema, dermatomyositis, and erythema nodosum respectively.

We are grateful to Professor G. A. Smart for permission to study a patient under his care, and to Dr. F. T. Farmer, Chief Physicist of the Royal Victoria Infirmary, for his helpful advice. 
We also wish to acknowledge that the work was supported by a grant from the Medical Research Council.

\section{REFERENCES}

Abrahams, I., McCarthy, J. T., and Sanders, S. L. (1963). Arch. Derm., $87,96$.

Chaplin, H., Mollison, P. L., and Vetter, H. (1953). ₹. clin. Invest., 32 1309.

Cohen, S., Freeman, T., and McFarlane, A. S. (1961). Clin. Sci., 20,
Dacie J. V., and Lewis, S. M. (1963). Practical Haematology, 3rd ed., p. 42. Churchill, London.

Fox, R. H., Shuster, S., Williams, R., Marks, J., Goldsmith, R., and Condon, R. E. (1965). Brit. med. F., 1, 619.

Hart, D., and Metz, J. (1962). f. clin. Path., 15, 459.

Ismail, A. A., Khalifa, K., and Madwar, K. R. (1965). Lancet, 2, 810. Ismail, A. A., Khalifa, K., and Madwar, K. R. (1965). Lancet, 2, 810. Invest., 11, 717 .

Marks, J., and Shuster, S. (1965). Unpublished observations.

Shuster, S., and Wilkinson, P. (1963). Brit. F. Derm., 75, 344.

Verel, D. (1958). Clin. Sci., 17, 639.

Weinbren, I. (1963). Lancet, 2, 544.

Wilson, H. T. H. (1954). Arch. Derm., 69, 577.

\section{Preliminary Communications}

\section{Acute Toxic Effects of Aflatoxin on Human Embryo Liver Cells in Culture}

Brit. med. F., 1966, 2, 90-91

The hepatotoxic effect of a number of metabolic compounds produced by fungi, particularly the aflatoxins formed by species of Aspergillus flavus and other toxins present in Penicillium islandicum, has recently been recognized (Sargeant et al., 1961 ; Uraguchi et al., 1961 ; Lancaster et al., 1961 ; Schoental, 1961). Observations have shown that the aflatoxins cause liver damage not only in poultry but also in lambs, pigs, and calves; and, in the laboratory, aflatoxins affected guinea-pigs, rats, and young rhesus monkeys. In addition to the acute hepatotoxic effects, aflatoxin $B_{1}$ has been shown to be a potent carcinogenic agent in rats (Dickens and Jones, 1963), trout (Ashley et al., 1964), and ducks (Carnaghan, 1965). There have been, however, very few reports on the activity of aflatoxin on cells grown in tissue culture. Juhász and Gréczi (1964) reported that extracts of groundnut-meal samples known to be contaminated with aflatoxins destroyed calf-kidney cells in tissue culture. Legator and Withrow (1964) noted that aflatoxin suppressed mitosis in human diploid and heteroploid embryo lung cells in culture. More recently Legator et al. (1965), using human embryo lung cells, found that aflatoxin suppressed synthesis of deoxyribonucleic acid. Giant-cell formation occurred in the tissue culture, and it was suggested that this could be accounted for by the enlargement of non-dividing cells.

There is strong suggestive evidence of the importance of hepatotoxins in the aetiology of human liver disease, such as veno-occlusive disease, cirrhosis, and primary carcinoma of the liver, particularly in the developing tropical and subtropical areas of the world. The significance of naturally occurring hepatotoxins in liver disease in the more sophisticated communities, however, should not be overlooked (Schoental, 1963 ; Brit. med. F., 1965). While it may be possible to translate experimental results in animals to man, since there are many parallels between the experimental lesions and the pathological lesions observed in man, the effect of natural hepatotoxins on human liver cells has not been studied.

Fulton (1960) described a method of implanting fragments of solid organs by squashing on to polythene discs to form a monolayer of cells without destroying the viability of the cells. Clotted mouse plasma is used as an adhesive. Implantation of tissue by this method gives rapid separation of the cells without destruction of the normal architecture of the tissue. Furthermore, the cells of the solid organ implanted have not undergone changes in morphology, differentiation, or transformation. The cells normally recover from the traumatic effect of implan- tation within a few hours and the monolayers can then be immediately used. We have employed this technique for culturing human embyro liver for the study of the effects of aflatoxin.

Livers were obtained by the Tissue Bank from human embryos at stages of gestation varying from 10 to 22 weeks. The livers were removed under strict aseptic conditions, placed in Medium 199, and transferred to the laboratory on melting ice. The liver was either cultured immediately or kept overnight at $+4^{\circ} \mathrm{C}$. Observations on the survival of the hepatic cells revealed the most suitable growth medium to be Eagle's minimal essential medium containing $0.15 \%$ bicarbonate and $10 \%$ foetal calf serum: Examination of the tissue immediately after implantation and several hours later showed complete recovery of the cells from the trauma of implantation. The hepatic cells remained viable for periods varying from 10 to 16 days.

Five hundred micrograms of purified aflatoxin $B_{1}$, kindly supplied by Dr. Kenneth R. Rees, was dissolved in $0.04 \mathrm{ml}$. of dimethyl formamide and diluted to contain 10 parts per million $(10 \mu \mathrm{g} . / \mathrm{ml}$.) in the growth medium. In later experiments the final concentration of aflatoxin was 5 parts per million $(5 \mu \mathrm{g}$./ ml.). Dimethyl formamide was used for the controls in the same dilutions, whereas other preparations were cultured on the growth medium alone. Implants were floated on the growth medium with and without aflatoxin and with and without dimethyl formamide. They were examined at varying intervals, as shown in the Table, by fluorescence microscopy after staining with freshly prepared $1 / 1,000$ acridine orange.

Effect of Aflatoxin B, on Preparations of Human Liver Cells in Tissue

\begin{tabular}{|c|c|c|c|c|c|c|}
\hline \multirow{3}{*}{$\begin{array}{c}\text { Time } \\
\text { Intervals } \\
\text { in } \\
\text { Hours }\end{array}$} & \multicolumn{4}{|c|}{ Concentration of Aflatoxin } & \multirow{3}{*}{$\begin{array}{c}\text { Diluent } \\
\text { Controls. } \\
\text { No. } \\
\text { Examined }\end{array}$} & \multirow{3}{*}{$\begin{array}{l}\text { Controls. } \\
\text { No. } \\
\text { Examiner }\end{array}$} \\
\hline & \multicolumn{2}{|c|}{$\begin{array}{c}10 \text { p.p. Million } \\
(10 \mu \mathrm{g} . / \mathrm{ml} .)\end{array}$} & \multicolumn{2}{|c|}{$\begin{array}{l}5 \text { p.p. Million } \\
(5, \mu \mathrm{g} / \mathrm{ml} .)\end{array}$} & & \\
\hline & $\begin{array}{c}\text { No. } \\
\text { Examined }\end{array}$ & $\begin{array}{l}\text { No. with } \\
\text { Cytopathic } \\
\text { Changes }\end{array}$ & $\begin{array}{c}\text { No. } \\
\text { Examined }\end{array}$ & $\begin{array}{l}\text { No. with } \\
\text { Cytopathic } \\
\text { Changes }\end{array}$ & & \\
\hline $\begin{array}{c}3-5 \\
16-24 \\
25-48\end{array}$ & $\begin{array}{r}5 \\
5 \\
10\end{array}$ & $\begin{array}{r}5 \\
5 \\
10\end{array}$ & $\begin{array}{r}6 \\
10 \\
4\end{array}$ & $\begin{array}{r}0 \\
10 \\
4\end{array}$ & $\begin{array}{r}5 \\
10 \\
9\end{array}$ & $\begin{array}{r}7 \\
11 \\
7\end{array}$ \\
\hline
\end{tabular}

The earliest microscopical changes were observed after three to five hours' exposure to aflatoxin in a concentration of 10 parts per million. These consisted of a change in the normal granular appearance of ribonucleic acid in the cytoplasm and loss of definition of the nucleoli. Marker cytopathic changes were observed after 16 hours' exposure. The overall dimensions of the hepatic cells were reduced and the cells rounded up. There was complete loss of orange (ribonucleic acid) fluorescence from the cytoplasm, and the cytoplasm was opaque 